\title{
The Relationship between Phonological Short-Term Memory and Foreign Language Vocabulary Learning in Children with and without Speech Sound Disorder
}

\author{
Ji Yeong Kima , Ji Wan $\mathrm{Ha}^{\mathrm{b}}$ \\ ${ }^{a}$ Department of Rehabilitation Science, Graduate School of Daegu University, Gyeongsan, Korea \\ ${ }^{b}$ Department of Speech Pathology, Daegu University, Gyeongsan, Korea
}

Correspondence: Ji-Wan $\mathrm{Ha}, \mathrm{PhD}$

Department of Speech Pathology, Daegu

University, 201 Daegudae-ro, Jillyang-eup,

Gyeongsan 38453, Korea

Tel: $+82-53-850-4327$

Fax: $+82-53-850-4329$

E-mail: jw-ha@daegu.ac.kr

Received: January 7, 2019

Revised: February 17, 2019

Accepted: February 27, 2019

This research was supported by the Daegu University Research Grant, 2017.

This work was an excerpt from the master's thesis of the first author (2018)
Objectives: The main purpose of this study was to compare the competence of phonological short-term memory and foreign language vocabulary learning between children with speech sound disorders (SSD) and their typically developing (TD) peers. In addition, this study tried to investigate the relationship among phonological short-term memory, other variables such as nonverbal intelligence and vocabulary knowledge, and foreign language word learning. Methods: The study subjects were 20 SSD children and 20 TD peers from 4 to 5 years of age. For this study, nonverbal intelligence, native (Korean) vocabulary knowledge, foreign (English) vocabulary knowledge, nonword repetition scores and English vocabulary learning scores were collected. Results: SSD children had lower scores in nonword repetition task and English vocabulary learning task than TD children. Also, nonword repetition ability was strongly influenced by percentage of correct consonants. And the receptive English vocabulary learning score was influenced by nonword repetition score whereas expressive English vocabulary learning score closely linked to English vocabulary knowledge. Conclusion: The findings suggest children with pure SSD are expected to have more trouble in learning English vocabulary because of low phonological short term memory. Thus, it is important to improve phonological short-term memory for successful English learning, and this can also be accomplished by increasing English vocabulary knowledge.

Keywords: Speech sound disorder, Phonological short-term memory, Nonword repetition, Foreign language vocabulary learning, English word learning, English vocabulary knowledge
말소리산출 결함은 다양한 원인에 의해서 발생할 수 있다. 청각 장애, 구개열, 뇌성마비 등 원인이 뚜렷한 경우도 있지만, 임상에서 만나는 말소리장애 아동들은 원인을 알 수 없는 경우가 대부분이 다. Diagnostic and Statistical Manual-5 (DSM-5)에서는 이 같은 원 인을 모르는 말소리 장애에 국한하여 ‘말소리장애(speech sound disorder)'로 진단할 것을 권고하고 있다. 여기서 말하는 원인을 알 수 없다는 것은 ‘원인이 없음’이 아니라 아직 원인이 밝혀지지 않았 거나, 말소리산출에 부정적 영향을 주는 여러 요인들이 존재한다 는 것을 의미한다. 결함을 초래한 일차적 원인을 밝히는 것은 중요
하지만 동시에 어렵고 요원한 일인 만큼, 최근 연구들은 말소리장 애와 관련 있는 기저요인들(underlying factors)을 밝히는 데에 보 다 초점을 두고 있다(Lee \& Ha, 2018). 기저요인들에 근거하여 이질 적인 말소리장애 집단을 하위집단들로 구분하고 각 하위집단별로 심층적인 평가와 중재 방향을 달리하는 것은 이들에 대한 치료의 효율성을 극대화시키기 위해 반드시 필요한 일이다.

여러 연구들에서 말소리장애의 기저요인으로 유전적 요인(Lewis et al., 2006), 반복적 중이염(Shriberg et al., 2003), 음운처리의 문제 (Lee \& Ha, 2018), 음운표상의 결함(Bae, Ha, Koo, Hwang, \& Pyun, 
Ji Yeong Kim, et al. • Phonological Short-Term Memory and Foreign Language Vocabulary Learning in SSD COMMUNICATION SCIINCES\& DISORDERS

2016; Kim \& Ha, 2014) 등이 보고된 바 있다. 이 중 음운표상 결함 에 관한 연구에서는 말소리장애 아동의 불명료한 음운표상이 어휘 습득 초기 형성 단계에서부터 발생하였을 가능성을 제시하였다 (Bae et al., 2016). 음운표상이란 장기기억 속에 저장된 어휘의 말소 리 정보를 의미한다. 아동들은 새로운 어휘를 접하게 되면 그에 대 한 의미정보와 더불어 말소리 정보, 즉 음운표상을 저장함으로써 해당 어휘를 습득한다. 즉, 장기기억에 음운표상을 명확하게 형성, 저장하여 일관되게 유지한 후 정확하게 인출하는 것은 새 어휘를 습득할 때 반드시 요구되는 과정이다. 따라서 음운표상의 초기 형 성에 어려움이 있는 말소리장애 아동의 경우, 이로 인해 알고 있는 어휘에 대한 부정확한 음운 산출뿐 아니라, 보다 근본적으로 새로 운 어휘 습득의 결함, 수용 또는 표현어휘량의 부족 등을 의심해 볼 수 있다.

새로운 어휘를 습득하는 것은 언어발달에 있어 기본적이면서 동 시에 오랜 기간 지속적으로 요구되는 과정이다. 더 나아가 이는 외 국어를 배울 때에도 기초 단계부터 고급 단계까지 끊임없이 요구되 는 과정으로, 이 경우 어휘 '습득(acquisition)'보다는 어휘 '학습 (learning)'이라는 표현이 더 적절할 것이다. Krashen (1978)에 의하 면 인간은 언어를 배울 때 습득과 학습이라는 두 과정을 거친다. 습 득은 자연스럽게 모국어를 터득하는 과정 중에 이루어지는 반면, 학습은 반복 연습 및 체계적인 규칙에 대한 설명과 훈련을 통해 이 루어진다. 우리나라의 경우 가장 보편적인 외국어는 영어이며, 한 국인들이 구사하는 영어는 대부분 교육을 통해 학습된 것, 즉 '제2 언어로서의 영어(English as a second language, ESL)'가 아닌 학교 환경에서 실시되는 '외국어로서의 영어(English as a foreign language, $\mathrm{EFL})^{\prime}$ 이다. EFL은 자연스러운 습득을 통해 이루어지는 ESL과는 환경이나 심리적 요소 등 여러 면에서 차이를 보이는데(Yang, Kim, $\mathrm{Kim}, \& \mathrm{Kim}, 2001)$, 이 경우 철저하게 훈련과 학습 과정이 강조된다.

외국어 학습에서 어휘를 익히는 것은 어렵지만 기본적이고 필수 적인 과정이다. 외국어 어휘학습과 관련된 인지 및 언어적 변인으 로 음운인식, 명명속도, 음운단기기억 등을 들 수 있는데, 이 가운 데 음운단기기억이 초기 외국어 학습자들에게 특히 중요한 것으로 보고되었다(Krashen, 1989). 그 이유는 EFL 환경에서 영어 어휘를 학습할 때 모국어로는 해당 어휘를 이미 알고 있는 경우가 대부분 이기 때문에, 익숙한 의미정보보다는 다른 언어체계의 음운정보를 저장하고 기억하는 활동을 통해 어휘를 익히게 되기 때문이다. 모 국어와 외국어 단어쌍을 짝지어 학습하는 연합과제에 대한 연구 (Papagno, Valentine, \& Baddeley, 1991), 비단어 용량(nonword span)과 제2언어 어휘학습과의 관련성에 관한 연구(Cheung, 1996) 등에서 외국어 어휘학습에 가장 영향을 주는 변인으로 음운단기
기억이 강조된 바 있다.

음운단기기억의 메커니즘은 Baddeley (2000)의 작업기억모델 (working memory model)에 잘 설명되어 있다. 작업기억은 여러 하 위요소들로 구성되어 있는데, 이 중 언어영역과 가장 관련 있는 요 소는 음운루프(phonological loop)이다. 음운루프는 음운정보를 일시적으로 보관하는 음운저장소(phonological store)와 소리 내지 않고 되뇌이는 조음메커니즘(sub-vocal rehearsal)으로 이루어져 있다. 외국어는 모국어에 비해 상대적으로 친숙하지 않은 음운정 보를 담고 있으므로, 외국어 학습 시 음운루프에서 음운정보를 효 율적으로 저장하여 이를 지속적으로 보유하는 능력이 더욱 요구 될 것이다. 한 어휘에 대한 또 다른, 더군다나 매우 생소한 음운조합 으로 구성된, 새로운 음운표상을 형성하고 저장해야 하는 부담감 이 있기 때문에, 외국어 학습 시 음운단기기억의 역할이 부각되는 것은 매우 당연해 보인다.

말소리장애 아동은 음운단기기억, 어휘력 등에서 일반아동보다 더 낮은 수행을 보인다는 여러 연구들을 찾아볼 수 있다(Aram \& Hall, 1989; Clark-Klein, 1994; Lee \& Sim, 2003; Seo, Ko, Oh, \& Kim, 2017). 최근에 실시된 Lee와 Ha (2018)의 연구에서도 비단어 따라 말하기를 통해 5,6 세의 일반아동과 말소리장애 아동의 음운단기 기억을 비교해 본 결과 말소리장애 아동의 수행력이 일반아동에 비해 유의미하게 더 낮았다고 보고하였다. 또한 음운처리능력과 외 국어 어휘학습 간 관련성에 대한 연구 $(\mathrm{Hu}, 2003)$ 에서는 아동의 모 국어 음운처리기술이 외국어 어휘학습을 예측하는 요인임을 밝혔 다. 이와 같은 연구들을 종합해 볼 때 음운단기기억에 결함이 있는 말소리장애 아동의 경우 일반아동에 비해 외국어 학습 시 그 어려 움이 가중될 것으로 예상된다. 그럼에도 불구하고 공교육에서 이 루어지는 영어 교육방식이나 시중에 나와 있는 영어 교재들은 일 반아동에만 초점을 두고 있다(Lee, 2008). 또한 순수 말소리장애 아동은 동반 장애 없이 말소리산출에만 문제가 있기 때문에, 대부 분 일반아동들과 동일한 환경에서 교육을 받는다. 이들이 본질적 으로 가지고 있는 음운단기기억 또는 음운표상의 결함 등으로 인 해 가중될 수 있는 외국어 교육의 어려움에 관해서는 전혀 논의가 이루어지지 않고 있는 실정이다.

따라서 본 연구에서는 말소리장애 아동이 실제로 음운단기기억 력에 결함을 보이는지 확인하고, 이러한 결함이 외국어 어휘학습 에 부정적인 영향을 미치는지를 살펴보고자 한다. 음운단기기억력 을 측정하는 방법으로는 비단어 따라말하기(nonword repetition) 과제를, 외국어 어휘학습 능력을 평가하는 방법으로는 영어 어휘 학습 과제를 이용하였다. 이를 위해 우선 말소리장애 아동과 일반 아동을 대상으로 비단어 따라말하기 과제와 영어 어휘학습 과제 
를 실시하여 두 집단 간 그 수행력에 차이가 있는지 확인하였다. 말 소리장애라는 집단의 특수성이 음운단기기억, 더 나아가 영어 어 휘학습에 미치는 영향을 밝히기 위해, 말소리산출 능력의 지표인 자음정확도가 비단어 따라말하기에 미치는 영향, 그리고 비단어 따라말하기가 영어 수용 및 표현어휘학습에 미치는 영향을 순차적 으로 알아보았다. 이때 음운단기기억과 외국어 어휘학습에 영향을 미치는 요인으로 선행연구들에서 보고된 바 있는 비언어성지능 (Farquharson, Hogan, \& Bernthal, 2018), 모국어 어휘력(Lee, Ha, Koo, Hwang, \& Pyun, 2016), 영어 어휘력(Gathercole \& Masoura, 2005)을 매개변인으로 설정하여 분석하였다. 이상과 같은 본 연구 의 연구질문을 정리해 보면 다음과 같다. 첫째, 말소리장애 아동과 일반아동 간 비단어 따라말하기 수행력에 차이가 있는가? 둘째, 자 음정확도는 비단어 따라말하기 수행력을 예측하는 요인인가? 이때 비언어성지능과 모국어 어휘력은 자음정확도와 비단어 따라말하 기의 관계를 매개하는 요인인가? 셋째, 말소리장애 아동과 일반아 동 간 영어 수용어휘학습 및 표현어휘학습 수행력에 차이가 있는 가? 넷째, 비단어 따라말하기 수행력은 영어 수용어휘학습과 표현 어휘학습의 수행력을 예측하는 요인인가? 이때 비언어성지능과 사 전 영어 어휘력은 비단어 따라말하기와 영어 수용 및 표현어휘학습 의 관계를 매개하는 요인인가?

\section{연구방법}

\section{연구대상}

본 연구의 대상은 4 세와 5 세의 말소리장애 아동 20 명과 일반아 동 20 명이었다. 말소리장애 아동은 전문 언어재활사에 의해 다른 장애를 동반하지 않고 말소리산출에만 결함을 보이는 순수 말소리 장애(pure speech sound disorder)로 진단받은 아동들이었다. 연구 자는 다음과 같은 기준을 적용하여 해당 아동이 순수 말소리장애 에 해당하는지 한 차례 더 확인하는 과정을 거쳤다. 그 기준은 첫 째, 감각적, 신경학적, 신체적으로 아무런 결함이 없는 것으로 부모 가 보고하였을 것, 둘째, 한국판 레이븐 지능검사 $(\mathrm{K}-\mathrm{CPM}$; Lim, 2004) 결과 비언어성지능이 85 이상에 해당할 것, 셋째, 수용·표현 어휘력검사(REVT; Kim, Hong, Kim, Jang, \& Lee, 2009) 결과 수용 및 표현어휘력이 -1 SD 이상에 해당할 것, 넷째, 우리말 조음-음운 평가(U-TAP; Kim \& Shin, 2004) 결과 단어 수준의 자음정확도가 $-2 \mathrm{SD}$ 이하에 해당할 것이었다. 이에 반해 일반아동 집단의 기준은 첫째, 부모의 보고에 의해 감각적, 신경학적, 신체적 결함이 없을 것, 둘째, K-CPM에서 비언어성지능이 85 이상에 해당할 것, 셋째, REVT 에서 수용 및 표현어휘력이 -1 SD 이상에 속할 것, 넷째 U-TAP에서
Table 1. Participants' characteristics

\begin{tabular}{lcc}
\hline & SSD group (N=20) & TD group (N=20) \\
\hline Chronological age (mo) & $58.40(6.19)$ & $60.45(5.00)$ \\
Nonverbal intelligence & $104.60(7.22)$ & $111.40(7.51)$ \\
Native receptive vocabulary score & $55.85(9.92)$ & $61.45(8.81)$ \\
Native expressive vocabulary score & $60.25(8.26)$ & $67.40(8.82)$ \\
English receptive vocabulary score & $9.30(10.65)$ & $17.40(11.24)$ \\
English expressive vocabulary score & $6.30(9.87)$ & $15.30(10.56)$ \\
PCC (\%) & $81.67(5.82)$ & $100(0)$ \\
\hline
\end{tabular}

Values are presented as mean (SD).

$\mathrm{SSD}=$ speech sound disorder; $\mathrm{TD}=$ typically developing children; $\mathrm{PCC}=$ percentage of consonants correct.

단어 수준의 자음정확도가 - $1 \mathrm{SD}$ 이상에 속할 것이었다. 또한 대상 자의 사전 영어 어휘력을 파악하기 위해, 모든 대상자에게 영어 사 전 수용어휘력 및 표현어휘력 검사를 실시하였다. 이에 대해서는 연구도구 부분에 자세히 설명되어 있으며, 한국어와 영어 간 구분 을 하기 위해 한국어는 모국어 수용어휘, 모국어 표현어휘로, 영어 는 영어수용어휘, 영어 표현어휘로 기술하였다.

말소리장애 집단과 일반 집단 간 성별 $\left(\chi^{2}=.102, p>.05\right)$, 생활 연 령 $(t=-1.15, p>.05)$, 모국어 수용어휘력 $(t=-1.88, p>.05)$ 에는 유의 한 차이가 없었다. 반면, 말소리장애 아동의 자음정확도는 평균 $81.67 \%$, 일반아동의 자음정확도는 평균 $100 \%$ 로, 두 집단 간 유의한 차이를 보였고 $(t=-14.073, p<.001)$, 비언어성지능 $(t=-2.92, p<.01)$, 모국어 표현어휘력 $(t=-2.647, p<.05)$, 영어 수용어휘력 $(t=-2.34$, $p<.05)$, 영어 표현어휘력 $(t=-2.786, p<.01)$ 에도 집단 간 유의한 차 이가 있었다. 말소리장애 집단의 경우 비언어성지능과 모국어 표현 어휘력이 정상 범주에는 속하나, 일반아동에 비해 그 수준이 유의 하게 떨어지는 것을 알 수 있다. 이와 같은 대상자 집단의 정보는 Table 1과 같다.

\section{연구도구}

\section{음운단기기억력검사}

음운단기기억 측정을 위해 선행연구에서 사용된 비단어 따라말 하기(Ryu \& Ha, 2018) 항목 가운데 3음절어 6개와 4음절어 4개를 채택하였다(Appendix 1). 채택된 항목들을 TTS (Text to Speech) 프로그램을 이용하여 소리자극 형태로 변환하여 오디오파일로 저 장하였고, 이를 대상자들에게 들려준 후 즉각적으로 따라하도록 하였다.

\section{사전 영어 수용어휘력 및 표현어휘력검사}

대상자들의 사전 영어 어휘력을 파악하기 위해, 교육부 지정 초 
Ji Yeong Kim, et al. • Phonological Short-Term Memory and Foreign Language Vocabulary Learning in SSD COMmuniCATION SCIINCES\& DISORDERS

등필수 영어 어휘 가운데 유치원 누리과정 의사소통영역에서 각 어 휘분류(신체운동 및 건강, 사회관계, 예술경험)에 해당하는 명사를 다수 선택하였다. 이 중 소리 변별이 어려운 단어(예: ship-sheep), 동음이의어(예: son-sun) 및 다의어(예: ball-공, 무도회)를 제외한 후, 최종적으로 27 개의 단어들을 선정하여 수용어휘력검사 항목 과 표현어휘력검사 항목으로 중복 사용하였다(Appendix 2). 영어 교사 10 명을 대상으로 각 문항을 5점 척도(1점은 매우 타당하지 않 음, 3 점은 보통, 5 점은 매우 타당함)로 하여 영어 어휘력 문항에 대 한 내용 타당도를 검증하였다(평균타당도 4.61). 영어 수용어휘력 검사는 TTS로 변환한 영어 단어의 오디오 파일을 아동에게 들려 준 후 그것이 무슨 의미인지 우리말로 말하게 하는 과제였고, 영어 표현어휘력검사는 동일한 의미를 가진 한국어를 아동에게 들려준 후 그것을 영어 단어로 산출하게 하는 과제였다. 검사의 난이도, 검 사에 대한 대상자들의 부담감 등을 고려하여 수용어휘력검사 실시 후 표현어휘력검사를 실시하였다.

\section{영어 수용어휘학습 및 표현어휘학습검사}

영어 어휘학습검사의 목표 어휘 선정을 위해 말소리장애 아동 5 명, 일반아동 10 명을 대상으로 사전 연구를 실시하여, 의미는 알고 있지만 그 이름을 영어로 알지 못하는 2음절의 영어 단어 3개(daikon, lizard, bugle)를 선정하였다. 아동으로 하여금 목표 어휘를 영 어 이름으로 3 회 반복하게 한 후 해당 어휘의 학습이 가능한지 확 인한 결과, 대부분의 아동이 영어 표현어휘학습검사에서 전혀 점 수를 획득하지 못하였다. 따라서 학습을 위해 단서를 보다 다양하 게 제시하여야 할 것으로 판단되었다. 초급 영어어휘학습자들을 위 한 효과적인 방법으로 다양한 단위에서의 어휘노출을 제안한 Kwon (2010)의 연구를 참고하여 목표 어휘를 문장 단위에서 우선적으로 제시하였다. 이에 따라 목표 어휘가 포함된 문장과 그에 해당되는 상황 그림을 제작하여, 대상자들에게 해당 단어에 대한 소리 단서, 그림 단서, 문맥 단서, 상황 단서들도 동시에 제공하도록 하였다. 또한 학습자가 해당 단어 이름을 소리 내어 여러 차례 반복하는 것이 새 어휘를 기억하는 데에 효과적이라는 Kim (2006)의 연구를 토대로, 단어 이름을 소리 내어 반복하는 것을 기존 3 회에서 5 회로 늘렸다.

영어 어휘학습검사의 학습 절차는 $\mathrm{Hu}$ (2003)의 '외국어 어휘 회 상 및 발음 학습(Foreign Language Word Recall and Pronunciation learning)' 절차를 수정, 보완한 것으로, 구체적인 방법은 다음 과 같다. 첫째, 하나의 영어 목표 어휘가 포함된 3개의 영어 문장을 상황 그림과 함께 제시하면서 한 번씩 들려준다. 둘째, 동일한 영어 목표 어휘에 해당하는 대상 그림과 철자가 쓰여진 플래시 카드를 보여주면서 그 이름을 들려준 후, 대상자로 하여금 영어로 따라하
기를 5 회 실시하게 한다. 셋째, 나머지 2 개의 영어 목표 어휘의 학습 도 동일한 방식으로 실시한다. 이상과 같은 학습 절차가 끝나면, 동 일한 영어 어휘에 대해 수용어휘학습검사와 표현어휘학습검사의 순서로 검사를 실시한다. 수용어휘학습검사는 3 개의 영어 어휘 그 림카드를 제시한 후, 제시한 그림에 해당되는 어휘를 들려주고 들 은 순서대로 그림카드를 짚는 방식으로 진행하였다. 표현어휘학습 검사에서는 3장의 목표 어휘 그림카드를 보여주며 보이는 순서대 로 해당그림을 영어로 말하는 방식으로 진행하였다. 두 검사 모두 문항마다 목표 어휘들의 순서를 달리하여 제시하였다. 예를 들어 수용어휘학습 1 번 문항에서 bugle-lizard-daikon의 순서로 목표 어 휘를 들려주었다면 2번 문항에서는 daikon-bugle-lizard, 3 번 문항 에서는 lizard-daikon-bugle과 같은 방식으로 들려주었다. 표현어 휘학습에서는 그림의 순서를 달리하여 제시하였다. 각 검사는 총 9 문항으로 구성하였다.

목표 어휘의 대상 그림과 상황 그림은 전문 일러스트레이터에게 의뢰하여 제작하였다. 목표 어휘의 단어 이름과 목표 어휘가 포함 된 문장은 TTS를 이용하여 소리로 변환한 후 오디오 파일로 저장 하였고, 각 오디오 파일은 이어폰을 통해 대상자에게 들려주었다. 그림 파일과 오디오 파일을 마이크로소프트 파워포인트에 삽입, 제작하여 아동에게 제시하였으며 검사에 사용된 문장과 그림은 Figure 1에 제시하였다.

\section{실험 절차}

실험은 아동이 재학하는 유치원 또는 거주하는 가정의 조용한 방에서 일대일로 실시하였다. 사전 검사로 발음검사(U-TAP), 비언 어성지능검사(K-CPM), 모국어 수용 및 표현어휘력검사(REVT)와 사전 영어 수용 및 표현어휘력검사(자체 제작)를 실시하였고, 실험 과제로 비단어 따라말하기와 영어 수용 및 표현어휘학습 과제를 실시하였다. 실험 과제를 실시하기 전, 아동이 지시 사항을 제대로 이해하였는지 확인하기 위해 연습 과제를 여러 차례 실시하였다. 또 한 영어 어휘학습 과제를 실시하기 전, 아동이 학습할 영어 단어를 모국어로 알고 있는지 그림을 보여주며 확인하는 절차를 거쳤다.

\section{자료처리 및 통계분석}

\section{비단어 따라말하기검사 점수}

비단어는 3 어절과 4 어절에서 각각 자음 18,16 개로 전체 자음수 는 34 개였다. 비단어 따라말하기 검사의 점수는 각 비단어 항목의 전체 자음에 대해 대상자가 정확하게 인출한 자음의 비율을 구한 후 100 을 곱하여 백분율로 산출하였다. 대치, 생략 및 첨가의 오류 는 오반응으로 처리하였으나, 왜곡의 경우 아동들, 특히 말소리장 


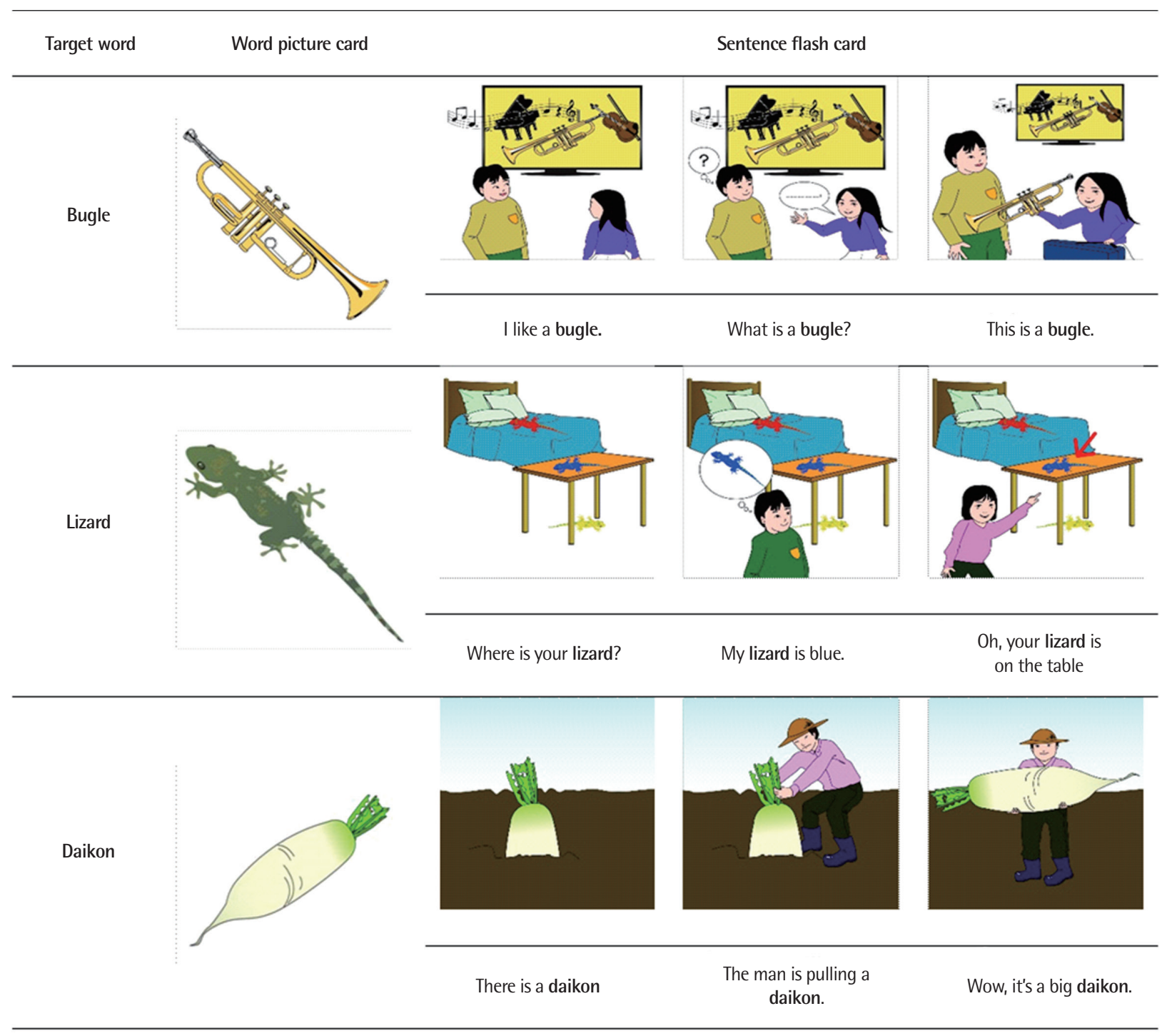

Figure 1. English vocabulary learning task.

애 아동들이 보이는 왜곡 오류는 음운적 차원이 아닌 운동적 측면 의 결함이라고 보고한 선행연구(Preston, Hull, \& Edwards, 2013) 에 근거하여 이는 정반응으로 처리하였다.

\section{사전 영어 수용어휘력 및 표현어휘력검사 점수}

사전 영어 어휘력검사는 영어 수용 및 표현어휘학습검사와 총점 을 동일하게 하기 위해, 아동이 정확하게 답을 할 경우 2점, 틀릴 경 우 0점으로 계산하였다. 수용어휘력 과제가 27항목, 표현어휘력 과 제가 27항목이므로, 사전 영어 수용어휘력검사와 표현어휘력검사 는 각각 54점 만점이었다.
영어 수용어휘학습 및 표현어휘학습검사 점수

영어 수용어휘학습검사와 표현어휘학습검사 모두 한 문항당 3 개의 목표 어휘를 제시하고, 문항 내에서 제시순서만 변경하는 방 식으로 총 9문항을 제시하였다. 즉, 대상자들에게 각 검사당 3 개의 어휘에 대해 9 회씩 총 27 회의 반응 기회를 제공하였다. 이때 수용어 휘학습검사는 영어 수용어휘력검사와 마찬가지로 정확하게 답할 경우 2점, 틀릴 경우 0점으로 계산하였고, 표현어휘학습검사는 부 분적으로 산출한 아동의 경우에도 점수를 부여하기 위해 음절단 위 채점방식을 채택하였다. 수용 및 표현어휘학습검사는 2음절로 이루어진(2점) 3 개의 목표 어휘가 9개 문항에서 각각 한 번씩 반복 제시되었으므로, 각 검사의 만점은 54 점 $(2$ 음절 $\times 3$ 단어 $\times 9$ 회 $)$ 씩 
Ji Yeong Kim, et al. • Phonological Short-Term Memory and Foreign Language Vocabulary Learning in SSD COMMUNICATION SCIINCES\& DISORDERS

이었다. 단, 선행연구( $\mathrm{Hu}, 2003)$ 에 근거하여 하나의 목표 어휘에 대 해 2회 연속 정반응할 경우, 나머지 7회의 제시 절차를 생략하고 해 당 항목은 모두 정반응한 것으로 처리하였다.

\section{통계분석}

자료의 통계처리는 SPSS version 23.0 (IBM, Armonk, NY, USA) 을 이용하여 다음과 같이 실시하였다. 첫째, 집단(말소리장애 집단 vs. 일반 집단) 간 음절길이(3음절 vs. 4음절)에 따른 비단어 따라말 하기 과제 점수에 차이가 있는지를 알아보기 위해 1피험자 간-1피 험자 내 혼합설계에 의한 반복측정 분산분석을 실시하였다. 집단 간 요인과 집단 내 요인의 상호작용효과를 구체적으로 분석하기 위 해서는 COMPARE syntax를 입력하여 사후검정을 실시하였다. 둘 째, 자음정확도가 비단어 따라말하기 수행력에 영향을 미치는지 를 알아보기 위해 단순회귀분석을 실시하였다. 본 연구의 말소리장 애 집단의 경우 자음정확도뿐 아니라 비언어성지능과 모국어 표현 어휘력에서도 그 수행력이 일반아동 집단보다 유의하게 떨어졌다 (Table 1). 비언어성지능과 어휘력이 음운단기기억력에 영향을 미친 다는 선행연구(Farquharson et al., 2018; Lee et al., 2016)를 고려할 때, 이러한 집단적 특성이 단순회귀분석 결과에 영향을 미쳤을 가 능성을 배제할 수 없다. 따라서 이를 확인하기 위해 비언어성지능 과 모국어 어휘력을 매개변수로 하여 위계적 다중회귀분석을 실시 하였다(Baron \& Kenny, 1986). 이때 모국어 어휘력은 REVT의 수 용어휘력과 표현어휘력의 원점수를 합한 값이다. 셋째, 집단(말소 리장애 집단 vs. 일반 집단) 간 과제유형(수용어휘학습 vs. 표현어휘 학습)에 따른 영어 어휘학습 수행력에 차이가 있는지 알아보기 위 해 1피험자 간-1피험자 내 혼합설계에 의한 반복측정 분산분석을 실시하였다. 넷째, 비단어 따라말하기 수행력이 영어 어휘학습 수 행력에 영향을 미치는지를 알아보기 위해 비단어 따라말하기와 영 어 수용어휘학습, 영어 표현어휘학습 간 단순회귀분석을 실시하였 다. 음운단기기억과 외국어 어휘학습에 비언어성지능과 사전 외국 어 어휘력(Gathercole \& Masoura, 2005)이 영향을 미친다는 선행 연구(Farquharson et al., 2018; Gathercole \& Masoura, 2005)를 고 려하여, 자음정확도와 비단어 따라말하기와의 관계, 비단어 따라 말하기와 영어수용어휘 및 표현어휘학습과의 관계에서 이들의 매 개효과가 있는지 알아보고자 비언어성지능과 사전 영어 어휘력을 매개변수로 하여 위계적 다중회귀분석을 실시하였다(Baron \& Kenny, 1986). 단순 회귀분석 및 위계적 다중회귀분석 시 집단을 구분 하지 않고 전체 대상자 $(\mathrm{N}=40)$ 로 분석하였으며, 이때 사전 영어 어 휘력은 영어 수용어휘력검사와 표현어휘력검사의 점수를 합한 값 이다.
Table 2. PCC in nonword repetition test

\begin{tabular}{lcc}
\hline & TD group (N=20) & Pure SSD group (N=20) \\
\hline 3-syllabled nonword & $65.00(12.88)$ & $55.56(9.71)$ \\
4-syllabled nonword & $64.06(18.24)$ & $46.38(16.30)$
\end{tabular}

Values are presented as mean (SD).

$\mathrm{SSD}=$ speech sound disorder; $\mathrm{TD}=$ typically developing children; $\mathrm{PCC}=$ percentage of consonants correct.

\section{연구결과}

\section{집단 간 음절길이에 따른 비단어 따라말하기 수행력 비교}

두 집단 모두 4음절보다 3음절 비단어 따라말하기에서 평균적 으로 수행력이 높았으며, 음절길이에 상관없이 순수 말소리장애 아 동 집단이 평균적으로 더 낮은 수행력을 나타내었다. 각 집단의 비 단어 따라말하기 검사의 수행력은 Table 2에 제시하였다.

이러한 차이가 통계적으로 유의한지 알아보기 위해 혼합설계에 따른 반복측정 분산분석을 실시한 결과, 집단간주효과 $\left(F_{(1,38)}=11.762\right.$, $p<.01)$ 와 음절길이에 따른 주효과가 유의하였다 $\left(F_{(1,38)}=4.387, p<\right.$ .05). 그러나 집단과 음절길이의 상호작용효과는 유의하지 않았다 $\left(F_{(1,38)}=2.911, p>.05\right)$.

\section{자음정확도가 비단어 따라말하기 수행력에 미치는 영향}

자음정확도와 비단어 따라말하기의 단순회귀분석 결과

앞서 말소리산출 결함 여부라는 집단 간 차이가 비단어 따라말 하기 점수에 유의한 차이를 초래한 것이 확인되었기 때문에, 말소 리산출 능력의 지표인 자음정확도와 비단어 따라말하기 점수 간 인과관계를 살펴보고자 하였다. 이에 자음정확도를 독립변인으로, 비단어 따라말하기 점수를 종속변인으로 하여 단순회귀분석을 실 시하였다. 그 결과 자음정확도가 비단어 따라말하기 점수에 미치 는 영향은 통계적으로 유의하였다 $(\beta=1.373, p<.001)$.

자음정확도와 비단어 따라말하기의 관계에 미치는 비언어성지능과 모국어 어휘력의 매개 효과

비언어성지능과 모국어 어휘력을 매개변수로 하여 위계적 다중 회귀분석을 실시한 결과, 비언어성지능을 매개변인으로 설정한 경 우 자음정확도의 표준화 베타가 2 단계 $(\beta=1.373)$ 보다 매개변수가 통제된 3단계( $\beta=1.469)$ 에서 오히려 증가하여, 비언어성지능은 자 음정확도와 비단어 따라말하기 점수 사이에 매개 역할을 하지 않 은 것이 확인되었다. 그러나 모국어 어휘력의 경우 자음정확도의 표준화 베타가 2 단계 $(\beta=.492)$ 보다 매개변수가 통제된 3 단계 $(\beta=$ $.400)$ 에서 감소하여, 모국어 어휘력은 두 변수 사이에 부분 매개 역 
Table 3. The scores of English learning task

\begin{tabular}{lcc}
\hline & TD group (N=20) & Pure SSD group (N=20) \\
\hline English receptive learning & $45.30(14.83)$ & $21.90(19.75)$ \\
English expressive learning & $16.05(10.18)$ & $6.30(10.16)$ \\
\hline
\end{tabular}

Values are presented as mean (SD).

$\mathrm{SSD}=$ speech sound disorder; TD = typically developing children.

할을 한 것을 알 수 있다.

\section{집단 간 과제유형에 따른 영어 어휘학습 수행력 비교}

두 집단 모두 영어 표현어휘학습에서보다 수용어휘학습에서 평 균적으로 높은 수행력을 보였으며, 과제유형에 상관없이 순수 말소 리장애 아동 집단이 일반아동 집단에 비해 더 낮은 수행력을 보였 다. 각 집단의 영어어휘학습 과제 수행력은 Table 3에 제시하였다.

이러한 차이가 통계적으로 유의한지 알아보고자 혼합설계에 따른 반복측정 분산분석을 실시한 결과, 집단 간 주효과 $\left(F_{(1,38)}=20.071\right.$, $p<.01)$, 과제유형에 따른 집단 내 주효과 $\left(F_{(1,38)}=74.701, p<.01\right)$, 집 단과 과제유형의 상호작용효과가 모두 유의하였다 $\left(F_{(1,38)}=6.919\right.$, $p<.05)$. 상호작용효과에 대해 사후검정을 실시한 결과 영어 수용 어휘학습 및 표현어휘학습 모두에서 두 집단 간 차이가 유의하였으 나 $(p<.001)$, 표현어휘학습검사에서는 일반 집단도 그 수행력이 매 우 떨어져 두 집단 간 차이는 수용어휘학습검사에서 두드러진 것 을 확인하였다.

\section{비단어 따라말하기 능력이 영어 수용어휘학습 수행력에 미치는 영향 \\ 비단어 따라말하기와 영어 수용어휘학습의 단순회귀분석 결과}

비단어 따라말하기가 영어 수용어휘학습에 미치는 영향을 알아 보기 위해 비단어 따라말하기 점수를 독립변인으로, 영어 수용어 휘학습 점수를 종속변인으로 하여 단순회귀분석을 실시하였다. 그 결과 비단어 따라말하기 점수가 영어 수용어휘학습 점수에 미치는 영향이 통계적으로 유의하였다 $(\mathrm{B}=.459, p<.001)$.

비단어 따라말하기와 영어 수용어휘학습의 관계에 미치는 비언어성지능과 사전 영어 어휘력의 매개 효과

비언어성지능 점수와 영어 수용 및 표현어휘력 점수를 합한 사전 영어 어휘력 점수를 매개변수로 하여 위계적 다중회귀분석을 실시 한 결과, 비언어성지능을 매개변인으로 설정한 경우 비단어 따라말 하기의 표준화 베타가 2 단계 $(\beta=.620)$ 보다 매개변수가 통제된 3 단 계( $\beta=.567)$ 에서 감소하였므로, 비언어성지능은 비단어 따라말하 기와 영어 수용어휘학습 점수 사이에서 부분 매개 역할을 한 것을

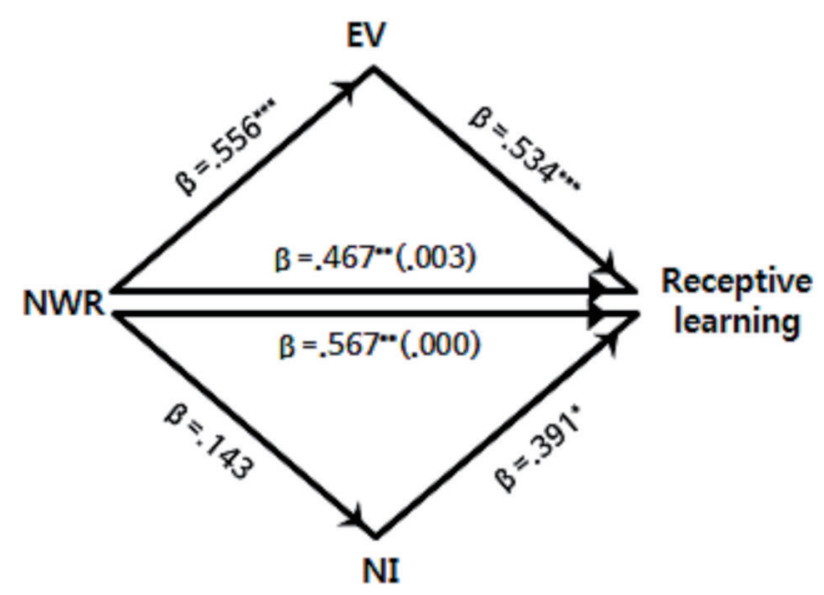

Figure 2. Mediated effect in nonword repetition (NWR) and English receptive vocabulary learning.

$\mathrm{EV}=$ English vocabulary; $\mathrm{NI}=$ nonverbal intelligence.

${ }^{*} p<.05,{ }^{* *} p<.01,{ }^{* * *} p<.001$.

알 수 있다. 사전 영어 어휘력의 경우도 비단어 따라말하기 점수의 표준화 베타가 2 단계 $(\beta=.620)$ 보다 매개변수가 통제된 3 단계 $(\beta=.467)$ 에서 감소하여, 영어 어휘력이 두 변수 간 부분 매개 역할을 한 것이 확인되었다. 이러한 네 변수 간 관계는 Figure 2 와 같이 도식화할 수 있다.

\section{비단어 따라말하기 능력이 영어 표현어휘학습 수행력에} 미치는 영향

비단어 따라말하기와 영어 표현어휘학습의 단순회귀분석 결과

비단어 따라말하기가 영어 표현어휘학습에 미치는 영향을 알아 보기 위해 비단어 따라말하기 점수를 독립변인으로, 영어 표현어 휘학습 점수를 종속변인으로 하여 단순회귀분석을 실시하였다. 그 결과 비단어 따라말하기 점수는 영어 표현어휘학습 점수에 유의한 영향을 미쳤다 $(\beta=.172, p<.01)$.

비단어 따라말하기와 영어 표현어휘학습의 관계에 미치는 비언어성지능과 사전 영어 어휘력의 매개 효과

비언어성지능 점수와 사전 영어 어휘력 점수를 매개변수로 하여 위계적 다중회귀분석을 실시한 결과, 비단어 따라말하기 점수의 표준화 베타가 2 단계 $(\beta=.434)$ 보다 매개변수가 통제된 3 단계 $(\beta=.371)$ 에서 감소하여, 비언어성지능이 비단어 따라말하기와 영어 표현어 휘학습 점수 사이에서 부분 매개 역할을 한 것으로 나타났다. 사전 영어 어휘력을 통제한 경우에도 비단어 따라말하기 점수의 표준화 베타가 2 단계 $(\beta=.434)$ 보다 매개변수가 통제된 3단계 $(\beta=.122)$ 에서 크게 감소하여 영어 어휘력 또한 비단어 따라말하기와 영어 표현어 
Ji Yeong Kim, et al. • Phonological Short-Term Memory and Foreign Language Vocabulary Learning in SSD

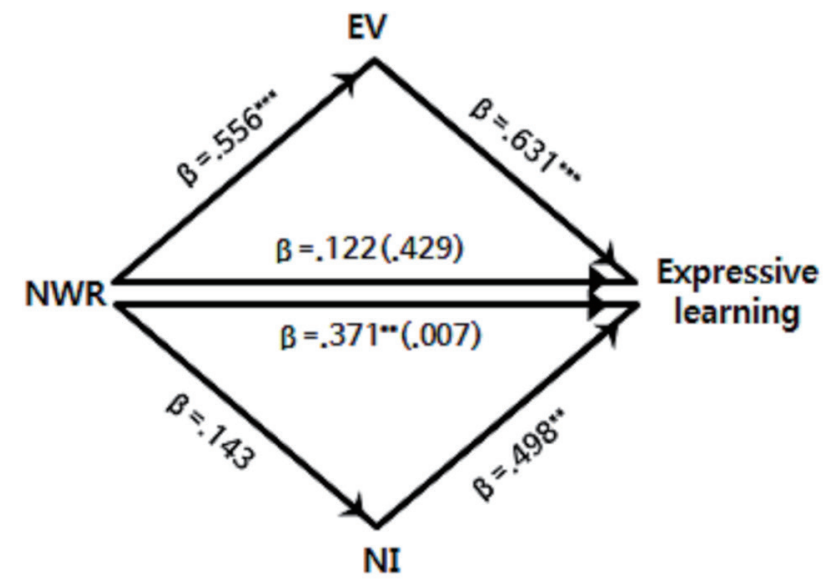

Figure 3. Mediated effect in nonword repetition (NWR) and English expressive vocabulary learning.

$\mathrm{EV}=$ English vocabulary; $\mathrm{NI}=$ nonverbal intelligence.

${ }^{*} p<.05,{ }^{* *} p<.01,{ }^{* * *} p<.001$.

휘학습 사이에서 매개 역할을 한 것을 알 수 있다. 그뿐만 아니라 3 단계에서 비단어 따라말하기 점수의 유의확률이 유의수준을 벗어 났으므로( $p>.05)$, 사전 영어 어휘력은 비단어 따라말하기와 영어 표현어휘학습에 완전 매개 역할을 한 것으로 해석할 수 있다. 이러 한 네 변수간 관계는 Figure 3과 같이 도식화할 수 있다.

\section{논의 및 결론}

본 연구는 말소리장애 아동과 일반아동을 대상으로 음운단기기 억력과 외국어 어휘학습 수행력을 비교하고 영어 어휘학습 시 음 운단기기억 및 관련변인들의 역할을 알아보기 위해 수행되었다. 그 결과 첫째, 말소리장애 아동 집단은 일반아동 집단에 비해 비단어 따라말하기 수행력이 유의하게 떨어져, 음운단기기억력에 결함이 있다는 것을 확인하였다. 둘째, 자음정확도와 비단어 따라말하기 점수 간 인과관계를 살펴본 결과, 자음정확도는 비단어 따라말하 기 수행력의 예측요인이었고 모국어 어휘력은 자음정확도와 비단 어 따라말하기 간 관계를 부분적으로 매개하는 요인이었다. 셋째, 말소리장애 아동 집단은 일반아동 집단에 비해 영어 수용 및 표현 어휘학습 수행력이 유의하게 떨어졌다. 넷째, 비단어 따라말하기 수행력과 영어 수용 및 표현어휘학습 수행력 간 인과관계를 살펴 본 결과, 비단어 따라말하기 수행력은 영어 수용 및 표현어휘학습 수행력을 예측하는 요인이었다. 그러나 비언어성지능과 사전 영어 어휘력을 매개변수로 투입한 결과 그 양상이 다소 상이하게 나타났 다. 비단어 따라말하기와 영어 수용어휘학습 간에는 비언어성지능 과 사전 영어 어휘력 모두 부분 매개요인으로 작용하였던 반면, 비
단어 따라말하기와 영어 표현어휘학습의 경우 비언어성지능은 부 분 매개요인이었으나 사전 영어 어휘력은 완전 매개요인의 역할을 하는 것으로 나타났다. 이러한 각각의 연구결과에 대해 다음과 같 은 해석이 가능하다.

우선 비단어 따라말하기 과제에서 말소리장애 아동은 일반아동 보다 유의하게 낮은 수행력을 보였는데, 이는 말소리장애 집단의 음운단기기억력 결함을 보고한 여러 연구들과(Lee \& Sim, 2003; Webster, Plante, \& Couvillion, 1997) 일치하는 결과이다. 그러나 순수 말소리장애 아동의 경우 그들의 음운단기기억력이 일반아동 과 차이가 없다는 연구 또한 찾아볼 수 있는데(Bishop \& Adams, 1990; Kim, 2017), 이러한 상반된 연구결과는 원인을 알 수 없는 말 소리장애 집단의 이질적 특성을 반영한 것으로 보인다. 순수하게 말소리산출에만 어려움이 있는 집단일지라도 그들이 가진 기저결 함은 청지각적 어려움, 음운표상의 저장, 접근 또는 인출의 문제, 음 운기억 또는 음운처리의 결함, 말운동 문제 등과 같이 다양하며 (Kim \& Ha, 2014), 이로 인해 음운루프의 능력도 대상자별로 차이 를 보일 것이다. 또한 두 집단 간 음절길이에 따른 비단어 따라말하 기 수행력을 비교한 결과에서는, 두 집단 모두 음절길이가 짧을 수 록 높은 수행력을 보였다. 이는 음절길이가 길어질수록 음운단기기 억 과제의 수행력이 저하된다는 Baddeley (1986)의 선행연구와도 일치하는 결과이다. 음운단기기억 과제수행 시 나타나는 음절길이 효과(length effect)는 되뇌이기(rehearsal)의 증거로 간주되며(Lee \& Sim, 2003), 되뇌이기 활동을 더욱 요구하는 4 음절 과제의 경우 말소리장애 아동뿐 아니라 일반아동 또한 어려움을 보이는 것을 알수있다.

말소리산출 결함이라는 집단 간 차이가 비단어 따라말하기 수행 력에 차이를 초래하였기 때문에, 말소리산출 능력의 지표인 자음정 확도가 대상자들의 비단어 따라말하기 수행력을 예측하는지를 알 아본 결과, 자음정확도는 비단어 따라말하기 수행력에 대한 강력 한 예측요인으로 나타났다. 이러한 결과는 비단어 따라말하기 점 수와 자음정확도가 정적 상관관계를 보고한 선행연구를 뒷받침해 준다(Jung \& Ha, 2017). 더 나아가 본 연구에서는 자음정확도와 비 단어 따라말하기의 관계에 영향을 줄 수 있는 비언어성지능과 모국 어 어휘력의 매개 효과를 살펴보았는데, 그 결과 모국어 어휘력만 이 두 변수 사이에 부분 매개 역할을 한 것으로 나타났다. 비언어성 지능의 매개 효과가 나타나지 않은 것은 두 집단 모두 평균 이상의 지능을 가진 대상자들로 구성되었고, 비언어성지능 과제가 언어 영 역과 관련이 적은 공간지각 및 추론 영역을 바탕으로 이루어져 있 기 때문으로 추측된다. 또한 들려주는 비단어를 즉각적으로 따라 하는 단기기억 과제는 인지적으로 크게 부담되는 과제가 아니기 때 
문에, 대상자의 지능이 과제 수행에 기여한 바가 없었던 것으로 여 겨진다. 반면 대상자의 어휘력은 여러 선행연구들에서 비단어 따라 말하기 과제에 영향을 미치는 요인으로 보고되었는데(Farquharson et al., 2018; Lee et al., 2016), 본 연구결과도 이러한 선행연구들 과 같은 맥락에서 해석할 수 있다. 본 연구의 말소리장애 아동들은 수용 및 표현어휘능력이 모두 정상 범주에 속하고 언어장애를 동 반하지 않은 것으로 진단받은 아동들이었으나, 사전 검사 결과 표 현어휘 원점수가 일반아동보다 유의하게 떨어지는 것이 확인되었 다. 자음정확도가 떨어진 아동은 어휘력 또한 부족하였고 자음정 확도와 어휘력은 둘 다 비단어 따라말하기 과제수행에 영향을 줄 수 있다는 점을 종합적으로 고려할 때, 비단어 따라말하기에 자음 정확도뿐 아니라 어휘력이 영향력 있는 요인으로 작용하였다는 본 연구결과는 타당한 것으로 여겨진다. 그러나 모국어 어휘력의 매개 효과를 배제하더라도 자음정확도는 여전히 비단어 따라말하기를 예측하는 요인이었다.

영어 어휘학습 과제에서는 수용 어휘학습과 표현 어휘학습검사 모두에서 말소리장애 아동이 일반아동보다 더 낮은 수행력을 보였 다. 이러한 결과는 말소리장애 아동의 경우 모국어의 새로운 어휘 를 학습할 때뿐 아니라(Bae et al., 2016), 외국어 어휘학습 시에도 어려움을 보인다는 것을 시사한다. 두 집단 모두 표현어휘학습보다 수용어휘학습 수행력이 유의하게 좋았고, 표현어휘학습검사의 경 우 일반아동도 그 수행력이 매우 떨어졌기 때문에 두 집단 간 차이 는 수용어휘학습검사에서 훨씬 더 두드러졌다. 모국어 어휘학습의 경우에도 유사한 결과가 보고된 바 있는데(Bae et al., 2016), 이는 과 제의 난이도와 관련된 것으로 보인다. 즉, 수용어휘학습 과제는 학 습한 어휘를 그림에서 찾는 활동으로, 입력된 음운정보를 일시적 으로 보유하는 수준에서 과제 수행이 가능하다. 반면 표현어휘학 습 과제는 학습한 어휘를 기억하여 영어로 말해야 하는 활동이기 때문에, 이를 위해서는 보유한 음운정보에 접근하여 산출까지 해 야하므로 음운처리와 관련하여 훨씬 부담감이 클 것이다.

새로운 어휘학습 시 음운단기기억력의 역할을 강조한 연구들 (Gathercole \& Masoura, 2005; Jeon, 2014; Papagno et al., 1991)에 근거하여, 이러한 결과가 대상자들의 음운단기기억 결함과 관련된 것인지를 알아보았다. 그 결과 대상자들의 비단어 따라말하기 수행 력은 영어 수용 및 표현어휘학습 수행력을 예측하는 요인으로 나 타났다. 이는 음운단기기억력이 뛰어난 학습자는 외국어 학습효과 가 더 높다는 선행연구들을 지지하는 결과이다 $(\mathrm{Hu}, 2003$; Jeon, 2014; Kim \& Choi, 2007). 그러나 비언어성지능과 사전 영어 어휘력 을 매개변인으로 설정하여 분석한 결과 수용어휘학습과 표현어휘 학습 과제 간 상이한 양상을 보였다. 비언어성지능과 사전 영어 어
휘력은 비단어 따라말하기와 수용어휘학습을 부분적으로 매개하 였고, 비단어 따라말하기는 수용어휘학습의 예측요인으로 여전히 유의하였다. 반면 표현어휘학습에서는 비언어성지능의 부분 매개 역할과 예측요인으로서 비단어 따라말하기의 유의성은 동일하였 으나, 사전 영어 어휘력이 두 변수 간 관계에 완전 매개요인으로 작 용하여 비단어 따라말하기가 예측요인으로서의 유의성을 상실하 였다.

수용과 표현어휘학습 모두에 나타난 비언어성지능의 부분 매개 역할은 새로운 어휘를 배울 때 대상자의 전반적 지능이, 그것이 꼭 언어성 지능이 아니더라도, 그 수행력에 영향을 줄 수 있음을 의미 하며, 따라서 이는 어휘학습 수행력이 단지 언어능력만을 반영하 는 것은 아닐 수 있음을 시사한다. 그러나 새로운 외국어 어휘학습 에 보다 큰 영향을 미친 것은 지능보다 대상자가 보유한 사전 어휘 지식이었다. 이는 비언어성지능보다 어휘력이 외국어 학습과 더 높 은 상관이 있다는 선행연구(Gathercole \& Masoura, 2005)를 지지 하는 결과이다. 흥미로운 점은 영어 표현어휘학습의 경우 대상자 들은 음운단기기억보다 기존에 보유하고 있는 영어 어휘지식에 전 적으로 의존하여, 음운단기기억이 그 영향력을 상실하였다는 것이 다. 앞에서 언급했듯이 표현어휘학습은 수용어휘학습보다 난이도 가 높은 과제로 이에 대한 성공적 수행을 위해서는 별도의 노력이 필요하다. 되뇌이기를 통해 새로운 음운표상 인출능력을 높일 수 있으나(Kim, 2017), 본 연구의 표현어휘학습 과제의 경우 난이도가 상당히 높아 5 회로 제한한 되뇌이기 활동만으로는 대상자들이 충 분한 이득을 얻지 못했을 수 있다. 이와 관련하여 효과적인 표현어 휘학습을 위해 요구되는, 되뇌이기 이외에 또 다른 전략에 대해서 는 추후 후속연구가 필요할 것이다. 또한 사전 영어 어휘력이 풍부 하다는 것은 이전에 영어학습 또는 영어사용 경험의 기회가 많았 을 가능성, 이전에 음운단기기억력이 양호하여 영어 어휘를 수월하 게 학습하였을 가능성 등을 모두 내포할 것이다. 이러한 여러 가능 성을 함축하고 있기 때문에 사전 어휘력이 높은 대상자일수록 난 이도가 높은 표현어휘학습 과제에서 수행력이 더 높았고, 그 결과 사전 어휘력이 표현어휘학습에 절대적인 영향을 미쳤을 가능성도 생각해볼수 있다.

이상과 같은 결론들을 정리해 보면, 아동의 모국어 말소리산출 능력은 음운단기기억 능력을, 음운단기기억 능력은 아동의 외국어 (영어) 어휘학습능력을 예측하는 지표이다. 그러나 이때 대상자의 지능과 사전 어휘력의 영향 또한 고려해야 한다. 대부분의 아동들 은 영어 어휘 습득 시 초기단계에는 보유한 어휘지식이 부족하므 로 음운단기기억 능력에 전적으로 의존할 것이다. 그러나 어휘학습 이 활발하게 일어나 보유한 어휘지식이 많아지면 그것을 바탕으로 
Ji Yeong Kim, et al. • Phonological Short-Term Memory and Foreign Language Vocabulary Learning in SSD COMMUNICATION SCIINCES\& DISORDERS

새 어휘를 학습하게 될 것이다. 다시 말해 영어 어휘학습에서 음운 단기기억은 새로운 어휘의 음운형태를 장기기억으로 전환하는 데 중요한 역할을 하며, 이렇게 저장된 장기지식은 음운단기기억 능력 을 높여 새 어휘학습을 용이하게 할 수 있다. 때문에 말소리장애 아 동의 경우 이러한 요인들 간 복잡한 상호작용결과로 인해, 모국어 와 외국어 모두에 있어 어휘학습의 어려움이 가중될 가능성이 있 다. 외국어를 효과적으로 가르치는 것은 교사의 몫일지라도, 모국 어 결함이 있는 학습자들의 성공적인 외국어 교육을 위한 실마리 를 제공하는 것은 언어병리학자의 과제일 것이다. 그런 의미에서 본 연구의 결과는 모국어에 결함이 있는 아동들을 위한 개별화된 외 국어 교수 방안을 모색하기 위한 출발점이 될 것으로 기대해 본다. 하지만 이러한 연구의 의의에도 불구하고 본 연구는 방법적 측면에 서 몇몇 제한점을 가지고 있다. 본 연구의 영어어휘학습 과제 점수 는 짧은 시간 반복하여 듣고 따라말하기 후 측정되었다. 이 같은 학 습형태는 음운단기기억능력에 의존한 방식이라 보여진다. 따라서 후속 연구에서는 실제 교실에서 이루어지는 학습처럼 어휘에 대한 노출시간을 더 늘이고 다양한 이해정보를 수반한 어휘학습 환경을 조성하고자 한다. 또한 본 연구에서 표집된 인원은 총 40 명으로 회 귀분석을 실시하여 결과를 분석하기에는 대상자 수가 다소 부족했 다고 보여진다. 따라서 각 집단별로 충분한 대상자를 모집하여 외 국어 학습과 관련 변인들의 관계성을 분석해 보는 후속연구가 이어 질 필요가 있다.

\section{REFERENCES}

Aram, D. M., \& Hall, N. E. (1989). Longitudinal follow-up of children with preschool communication disorders: treatment implications. School Psychology Review, 18(4), 487-501.

Baddeley, A. D. (1986). Working memory. New York, NY: Oxford University Press

Baddeley, A. D. (2000). The episodic buffer: a new component of working memory? Trends in Cognitive Sciences, 4(11), 417-423.

Bae, S. R., Ha, J. W., Koo, M. M., Hwang, Y. M., \& Pyun, S. B. (2016). New phonological representation of children with speech sound disorders. Communication Sciences \& Disorders, 21(1), 24-36.

Baron, R. M., \& Kenny, D. A. (1986). The moderator-mediator variable distinction in social psychological research: conceptual, strategic, and statistical considerations. Journal of Personality and Social Psychology, 51(6), 1173-1182.

Bishop, D. V., \& Adams, C. (1990). A prospective study of the relationship between specific language impairment, phonological disorders and reading retardation. Journal of Child Psychology and Psychiatry, 31(7), 10271050.

Cheung, H. (1996). Nonword span as a unique predictor of second-language vocabulary language. Developmental Psychology, 32(5), 867-873.

Clarke-Klein, S. M. (1994). Expressive phonological deficiencies: impact on spelling development. Topics in Language Disorders, 14(2), 40-55.

Farquharson, K., Hogan, T. P., \& Bernthal, J. E. (2018). Working memory in school-age children with and without a persistent speech sound disorder. International Journal of Speech-Language Pathology, 20(4), 422-433.

Gathercole, S. E., \& Masoura, E. V. (2005). Contrasting contributions of phonological short-term memory and long-term knowledge to vocabulary learning in a foreign language. Memory, 13(3-4), 422-429.

Hu, C. F. (2003). Phonological memory, phonological awareness, and foreign language word learning. Language Learning, 53(3), 429-462.

Jeon, J. H. (2014). A study of the influences of phonological short-term memory and existing vocabulary knowledge on L2 vocabulary acquisition. Journal of Language Science, 21(4), 167-191.

Jung, S. M., \& Ha, S. H. (2017). The relationship among nonword repetition, age, vocabulary and articulation ability. Communication Sciences \& Disorders, 22(1), 14-24

Kim, M. J. (2017). Nonword repetition ability according to auditory input enhancement and vocal rehearsal in children with and without speech sound disorder (Master's thesis). Daegu University, Gyeongsan, Korea.

Kim, N. Y., \& Ha, J. W. (2014). Phonological representations in children with articulation and phonological disorders. Communication Sciences \& Disorders, 19(2), 226-237.

Kim, S. (2006). Effects of phonological short-term memory, learning styles and oral repetition on English vocabulary learning (Master's thesis). Ewha Womans University, Seoul, Korea.

Kim, S. J., \& Choi, Y. H. (2007). Effects of phonological short-term memory, learning styles, and oral repetition on middle school students' learning of English vocabulary. Foreign Languages Education, 14(1), 243-270.

Kim, Y. T., Hong, G. H., Kim, K. H., Jang, H. S., \& Lee, J. Y. (2009). Receptive ఓ expressive vocabulary test (REVT). Seoul: Seoul Community Rehabilitation Center

Kim, Y. T., \& Shin, M. J. (2004). Urimal Test of Articulation and Phonology (U-TAP). Seoul: Hakjisa.

Krashen, S. (1978). Individual variation in the use of the monitor. In W. C. Ritchie (Ed.), Second language acquisition research: issues and implications 
(pp. 175-183). New York, NY: Academic Press.

Krashen, S. (1989). We acquire vocabulary and spelling by reading: additional evidence for the input hypothesis. The Modern Language Journal, 73(4), 440-464.

Kwon, J. H. (2010). The study of vocabulary learning strategies (Master's thesis). Ajou University, Suwon, Korea.

Lee, E. J., \& Sim, H. S. (2003). Phonological memory in the nonword repetition of children: a comparison of functional phonologically disordered and normal children. Korean Journal of Communication \& Disorders, 8(2), 127-145.

Lee, J. (2008). Handicap awareness and attitude in English language teaching. The Journal of Modern British \& American Language \& Literature, 26(2), 87-103.

Lee, K. E., \& Ha, J. W. (2018). Phonological short-term and working memory in 5-and 6-year-old children with speech sound disorders. Communication Sciences \& Disorders, 23(3), 713-724.

Lee, S. J., Ha, J. W., Koo, M. M., Hwang, Y. M., \& Pyun, S. B. (2016). Delayed non-word repetition according to rehearsal conditions in 6-to 7-year-old children. Communication Sciences \& Disorders, 21(1), 69-83.

Lewis, B. A., Freebairn, L. A., Hansen, A. J., Stein, C. M., Shriberg, L. D., Iyengar, S. K., \& Taylor, H. G. (2006). Dimensions of early speech sound disorders: a factor analytic study. Journal of Communication Disorders, 39(2), 139-157.

Lim, H. C. (2004). Korean Raven's Coloured Progressive Matrix. Seoul: Han- kuk Guidance.

Papagno, C., Valentine, T., \& Baddeley, A. (1991). Phonological short-term memory and foreign-language vocabulary learning. Journal of Memory and Language, 30(3), 331-347.

Preston, J. L., Hull, M., \& Edwards, M. L. (2013). Preschool speech error patterns predict articulation and phonological awareness outcomes in children with histories of speech sound disorders. American Journal of SpeechLanguage Pathology, 22(2), 173-184.

Ryu, E., \& Ha, J. W. (2018). Non-word repetition task of typically developing children: Analysis from retrieval and sequencing errors. Proceedings of the Korean Society of Speech Sciences Spring Conference, Daejeon, Korea.

Seo, E. Y., Ko, Y. K., Oh, G. A., \& Kim, S. J. (2017). Phonological awareness and vocabulary characteristics of children with speech sound disorders. Communication Sciences \& Disorders, 22(2), 318-327.

Shriberg, L. D., Kent, R. D., Karlsson, H. B., Mcsweeny, J. L., Nadler, C. J., \& Brown, R. L. (2003). A diagnostic marker for speech delay associated with otitis media with effusion: backing of obstruents. Clinical Linguistics \& Phonetics, 17(7), 529-547.

Webster, P. E., Plante, A. S., \& Couvillion, L. M. (1997). Phonologic impairment and prereading: update on a longitudinal study. Journal of Learning Disabilities, 30(4), 365-375.

Yang, O. S., Kim, Y. S., Kim, J. Y., \& Kim, H. H. (2001). The appropriateness of early childhood English education. The Journal of Korean Education, 28(2), 347-367. 
Ji Yeong Kim, et al. • Phonological Short-Term Memory and Foreign Language Vocabulary Learning in SSD COMMuniCATION SCIINCES\& DISORDeRS

Appendix 1. The list of non-word repetition stimuli

\begin{tabular}{cccc}
\hline \multicolumn{2}{c}{ 3음절 비단어 } & \multicolumn{2}{c}{ 4음절 비단어 } \\
\hline 그쪼버 & 히너쁘 & 느쩌히꾸 & 뻐히쪼므 \\
쪼두프 & 꼬니뜨 & 머삐꾸쪼 & 쿠버쪼느 \\
쁘쩌니 & 삐머트 & & \\
\hline
\end{tabular}

Appendix 2. The word list of English vocabulary knowledge

\begin{tabular}{cccccc}
\hline \multicolumn{2}{c}{ 사전 영어 수용어휘력 검사항목 } & \multicolumn{3}{c}{ 사전 영어 표현어휘력 검사항목 } \\
\hline Hand & Finger & Face & 손 & 손가락 & 얼굴 \\
Egg & Sugar & Grape & 달걀 & 설탕 & 포도 \\
Dish & Candle & Window & 접시 & 양초 & 창문 \\
Rain & Sky & Pig & 비 & 하늘 & 돼지 \\
Fish & Monkey & Winter & 물고기 & 원숭이 & 겨울 \\
Train & Car & Airplane & 기차 & 자동차 & 비행기 \\
Doctor & Queen & Sister & 의사 & 여왕 & 여자형제 \\
Pencil & Balloon & Desk & 연필 & 풍선 & 책상 \\
Red & Yellow & Green & 빨간색 & 노란색 & 초록색 \\
\hline
\end{tabular}




\section{국문초록}

\section{말소리장애 아동과 일반아동의 음운단기기억과 외국어 어휘학습과의 관계 김지영' $\cdot$ 하지완 ${ }^{2}$ \\ ${ }^{1}$ 대구대학교 일반대학원 재활과학과 언어치료전공, ${ }^{2}$ 대구대학교 언어치료학과}

배경 및 목적: 본 연구는 말소리장애 아동과 일반아동을 대상으로 음운단기기억능력과 외국어 어휘학습 수행력을 비교해 보고 외국 어 어휘학습 시 음운단기기억 및 관련변인들의 역할을 알아보고자 하였다. 방법: 순수 말소리장애 아동 20 명과 일반아동 20 명을 대상 으로 음운단기기억 능력 측정을 위해 음절길이를 달리한 비단어 따라말하기 과제를 실시하였다. 외국어 어휘학습 과제로는 아동에게 의미는 알지만 영어로는 알지 못하는 새로운 영어 단어를 학습시킨 후 수용 및 표현학습 과제로 나누어 그 수행력을 비교해 보았다. 결 과: 비단어 따라말하기 과제에서는 음절길이에 상관없이 말소리장애 아동이 낮은 수행을 나타내었으며 이때 아동의 자음정확도와 비 단어 따라말하기는 밀접한 관련이 있었다. 또한 영어 어휘학습 과제에서도 과제유형에 상관없이 말소리장애 아동이 유의하게 낮은 수 행을 보였으며 비단어 따라말하기 점수는 수용어휘학습 점수에서 많은 기여를 한 반면, 표현어휘학습에서는 기존에 아동이 가진 영어 어휘력의 기여도가 더 높은 것으로 나타났다. 논의 및 결론: 말소리장애 아동들은 모국어의 말소리산출의 어려움과 낮은 음운단기기 억능력으로 인해 외국어 학습에서도 그 어려움이 가중될 수 있다. 말소리장애 아동의 효과적인 외국어 학습을 위해서는 음운단기기억 능력을 높이는 것이 중요하며, 해당 언어의 어휘력을 향상시키는 것 또한 이에 도움이 될 수 있을 것이다.

핵심어: 말소리장애, 비단어 따라말하기, 음운단기기억, 외국어 어휘학습, 외국어 어휘력

본 논문은 2017학년도 대구대학교 학술연구비지원에 의한 논문임.

본 논문은 제 1 저자의 석사학위논문 내용을 바탕으로 작성되었음.

\section{참고문헌}

권준호(2010). 효과적인 영어어휘학습 전략연구. 아주대학교 대학원 석사학위논문.

김나연, 하지완(2014). 조음음운장애아동과 일반아동의 음운표상의 질과 음운표상 부호화 능력 비교. Communication Sciences \& Disorders,

19(2), 226-237.

김미진(2017). 외현적 시연과 청각적 입력 강화가 말소리장애아동과 일반아동의 비단어 따라말하기 수행력에 미치는 영향. 대구대학교 대학원 석사

학위논문.

김서종(2006). 음운단기기억 능력과 학습자 성향 및 구두반복 학습이 한국 중학교 학생들의 영어 어휘 학습에 미치는 영향. 이화여자대학교 대학원 석사학위논문.

김영태, 신문자(2004). 우리말조음-음운평가(U-TAP). 서울: 학지사.

김영태, 홍경훈, 김경희, 장혜성, 이주연(2009). 수용- 표현어휘력검사(REVT). 서울: 서울장애인종합복지관.

류은주, 하지완(2018). 일반아동의 비단어 따라말하기 과제분석: 인출과 배열 오류 중심으로. 2018년 한국음성학회 봄 학술대회 발표논문집, 41-42. 배세령, 하지완, 구민모, 황유미, 편성범(2016). 말소리장애 아동의 새로운 음운표상 형성능력. Communication Sciences \& Disorders, 21(1), 24-36.

서은영, 고유경, 오경아, 김수진(2017). 말소리장애 아동의 음운인식과 어휘특성. Communication Sciences \& Disorders, 22(2), 318-327.

양옥승, 김영실, 김진영, 김현희(2001). 유아 영어교육의 적합성. 한국교육, 23(2), 347-367.

이기은, 하지완(2018). 5세와 6세 말소리장애 아동의 음운단기기억과 음운작업기억 능력. Communication Sciences \& Disorders, 23(3), 713-724.

이석정, 하지완, 구민모, 황유미, 편성범(2016). 6, 7세 아동의 시연조건에 따른 지연 비단어따라말하기 능력 비교. Communication Sciences \& Disor-

ders, 21(1), 69-83.

이은주, 심현섭(2003). 무의미 음절 따라말하기를 통한 단순조음음운장애 아동과 정상아동의 음운기억 수행능력 비교연구. 언어청각장애연구, 8(2), 
Ji Yeong Kim, et al. • Phonological Short-Term Memory and Foreign Language Vocabulary Learning in SSD COMMUNICATION SCIINCES\& DIIORDERS

127-145.

이종복(2008). 영어 교육에 있어서 장애에 대한 인식과 태도. 현대영미어문학, 26(2), 87-103.

임호찬(2004). 한국판 레이븐 지능검사(CPM 지침서). 서울: 한국가이던스.

전지현(2014). L2 어휘지식 습득에 있어 음운단기기억과 기존 어휘지식의 영향에 관한 연구. 언어과학, 21(4), 167-191.

정소미, 하승희(2017). 비단어 따라말하기와 연령, 어휘 및 조음능력과의 관계. Communication Sciences \& Disorders, 22(1), 14-24.

\section{ORCID}

김지영(http://orcid.org/0000-0001-7732-1521); 하지완(http://orcid.org/0000-0002-1191-791X) 